\title{
Recent Experiences with Currency Substitution
}

\author{
Hisao Kumamoto ${ }^{1}$ \\ ${ }^{1}$ Faculty of Economics and Business Administration, Fukushima University, Fukushima, Japan \\ Correspondence: Hisao Kumamoto, Faculty of Economics and Business Administration, Fukushima University, 1 \\ Kanayagawa, Fukushima, 960-1296, Japan. Tel: 81-24-548-8434. E-mail: e010@ipc.fukushima-u.ac.jp \\ Received: June 13, 2014 \\ Accepted: July 2, $2014 \quad$ Online Published: August 24, 2014 \\ doi:10.5430/ijfr.v5n4p1 \\ URL: http://dx.doi.org/10.5430/ijfr.v5n4p1
}

\begin{abstract}
We empirically investigate recent experiences with currency substitution. We focus especially on the determinants of currency substitution, namely, the factors representing the usefulness of a foreign currency both as a medium of exchange and a store of value. This paper has three key distinguishing features. First, our sample includes eight developing and/or emerging countries from different regions to permit direct cross-country comparison, unlike in many previous studies. Second, this study covers a recent sample period. The U.S. dollar and the euro have been depreciating against other currencies since the 2007 financial crisis, and have therefore become less useful as a store of value. Therefore, it is important that we investigate whether the determinants of currency substitution have changed in recent periods. Third, we derive an estimated equation from the agent's utility maximization problem. In particular, we introduce the exchange rate risk premium as an alternative determinant, considering its relevance to the forward premium puzzle - the failure of the interest rate differential to correctly represent expected changes in the nominal exchange rate and hence the usefulness of foreign currency as a store of value. The empirical results indicate that the variables representing the usefulness of foreign currency both as a medium of exchange and a store of value are significant determinants of currency substitution. The results show that currency substitution has important monetary policy implications.
\end{abstract}

Keywords: currency substitution, network externalities, ratchet effects, foreign currency, domestic currency, euro

\section{Introduction}

Currency substitution is a phenomenon in which domestic residents use foreign currency in their economic transactions. It is observed especially in high-inflation economies such as Latin American countries, some Asian countries, and Central and Eastern European transition countries.

Domestic residents would determine whether they should use domestic or foreign currency by comparing their usefulness as a medium of exchange and a store of value. With high inflation, domestic residents fear that the domestic currency would be less useful as a store of value. Therefore, they would look for alternatives such as the U.S. dollar or euro. (Note 1)

On the other hand, the usefulness of a currency as a medium of exchange depends on its general acceptability. That is, the greater the number of domestic residents using a currency, the more useful it becomes. That is, the higher the degree of currency substitution in a country, the more useful is foreign currency as a medium of exchange. Therefore, even if the inflation rate (and hence the nominal interest rate and the expected change in the nominal exchange rate) in the domestic country falls, domestic residents would continue to use foreign currency if they consider it more useful as a medium of exchange than is the domestic currency as a store of value. This phenomenon is typically referred to as the ratchet effect, or hysteresis, of currency substitution. That is to say, currency substitution increases rapidly with macroeconomic destabilization but decreases only slightly, or not at all, after stabilization. Uribe (1997) and Peiers and Wrase (1997) show that as the economy's accumulated experience in using foreign currency as a medium of exchange acts as a network externality, it reduces the marginal cost of buying goods with foreign currency. This network externality produces ratchet effects of currency substitution. (Note 2)

Many previous studies have investigated currency substitution. (Note 3) However, most of them considered a single country or a few countries within the same region, making comparative studies among countries and regions impossible. Furthermore, they focused on sample periods characterized by macroeconomic destabilization (high inflation, expansion of the interest rate differential, and depreciation of the domestic currency vis-à-vis the U.S. 
dollar or euro). However, more recent years, especially the period after the 2007 financial crisis, have witnessed relative macroeconomic stabilization (lower inflation, reduction of the interest rate differential, and depreciation of the U.S. dollar and euro against other currencies). Therefore, investigating currency substitution in that era would be a meaningful exercise.

The purpose of this paper is to empirically investigate recent currency substitution experiences of eight developing and/or emerging countries located in different regions: Indonesia, the Philippines, Tajikistan, the Czech Republic, Hungary, Poland, Argentina, and Peru. In particular, we focus on the determinants of currency substitution, that is, the factors representing the usefulness of foreign currency both as a medium of exchange and a store of value. This paper has three key distinguishing features.

First, our sample comprises eight countries from different regions-Asia, Eastern Europe, and Latin America. This geographical spread allowed a direct cross-country comparison unlike in previous studies.

Second, this study covers a recent sample, focusing on the period after the 2007 financial crisis. Since the financial crisis, the U.S. dollar and euro have been depreciating against other currencies. That is, the usefulness of the U.S. dollar and euro has diminished over the years. Therefore, we need to investigate whether the determinants of currency substitution have changed recently.

Third, we derive an estimated equation from the agent's utility maximization problem, which is represented by a currency substitution-type money-in-the-utility-function model with network externalities. In particular, we introduce the exchange rate risk premium as an alternative determinant. This is important in the context of the so-called forward premium puzzle. (Note 4) When covered interest parity holds, uncovered interest parity indicates that the forward premium (and hence the interest rate differential) should be an unbiased predictor of the ex-post movement in the spot exchange rate (and hence the expected change of nominal exchange rate) under the assumption of rational expectations. However, several previous works claim that forward premium is a biased predictor of the actual movement in the exchange rate. This means the interest rate differential could not correctly represent the expected change of nominal exchange rate, namely, the usefulness of foreign currency as a store of value.

Our analysis can be expected to have some monetary policy implications. Previous theoretical and empirical studies show that currency substitution could have significant effects on the independence of monetary policy and exchange rate stability under a flexible exchange rate system (e.g., Girton and Roper, 1981; Kareken and Wallace, 1981; Rogers 1990; Akçay, Alper, \& Karasulu, 1997; Kumamoto \& Kumamoto, 2004). For example, a high degree of currency substitution has been shown to cause the nominal interest rate to react strongly to even small monetary policy changes. This makes the nominal exchange rate more volatile. Moreover, currency substitution would restrict the ability of monetary policy to isolate domestic economy from foreign shocks. On the other hand, under a fixed exchange rate system, currency substitution could significantly affect sustainability of currencies in a fixed exchange rate system (e.g., Giovannini, 1991; Sawada \& Yotopoulos, 2002). For example, it is shown that a higher degree currency substitution can lead to greater variability of foreign exchange reserves. Moreover, even if the central bank does not expand domestic credit excessively, the more pronounced currency substitution is in a country, the earlier a currency crisis tends to occur, and the stronger it is.

From the above arguments, even when the central bank decides to reduce currency substitution through macroeconomic stabilization in order to restore the domestic currency as a useful store of value, currency substitution will not decrease rapidly if the ratchet effect is strong.

This paper is organized as follows. Section 2 derives the estimation equation and describes the econometric methodology. Section 3 presents the data and illustrates the recent status of currency substitution in the sample countries. Section 4 discusses the econometric results and provides their monetary policy implications. Finally, Section 5 concludes the study.

\section{Empirical Methodology}

First, we derive an estimated equation following Kumamoto and Kumamoto (2008), who introduce currency substitution through the money-in-the-utility-function framework with network externalities in currency substitution.

We consider a small open economy where the price level is flexible and capital mobility is perfect. We assume many identical infinitely living households obtaining utility from real consumption and real balances of domestic and foreign money. We also assume that the utility obtained from holding foreign currency depends on knowing how to use it as a medium of exchange. Therefore, at time $t$, a typical household maximizes the following expected value of a discounted stream of period utility: 
where

$$
\max _{\left\{B_{t}, B_{t}^{*}, M_{t}, M_{t}^{*}\right\}} U_{t}=\sum_{s=t}^{\infty} \beta^{s-t} E_{t}\left[u\left(C_{s}, M_{s} / P_{s}, M_{s}^{*} / P_{s}^{*}\right)\right]
$$

$$
\begin{gathered}
u_{t}=C_{t}+\gamma X_{t}, \quad X_{t}=\left[\left\{1-\delta\left(K_{t}\right)\right\}\left(M_{t} / P_{t}\right)^{-\varepsilon}+\delta\left(K_{t}\right)\left(M_{t}^{*} / P_{t}{ }^{*}\right)^{-\varepsilon}\right]^{-(1 / \varepsilon)}, \\
\text { s.t. } \quad\left(B_{t} / P_{t}\right)+\left(B_{t}{ }^{*} / P_{t}^{*}\right)+\left(M_{t} / P_{t}\right)+\left(M_{t}{ }^{*} / P_{t}{ }^{*}\right)=Y_{t}+\left(1+i_{t-1}\right)\left(B_{t-1} / P_{t}\right)+\left(1+i_{t-1}{ }^{*}\right)\left(B_{t-1}{ }^{*} / P_{t}{ }^{*}\right)+\left(M_{t-1} / P_{t}\right)+\left(M_{t-1}{ }^{*} / P_{t}{ }^{*}\right)-C_{t},
\end{gathered}
$$

$\gamma>0,0<\delta(\cdot)<1, \delta(1)=1 / 2, \delta$ '( $)>0, \varepsilon>-1, C_{t}$ is real consumption, $M_{t}$ and $M_{t}^{*}$ are nominal balances of domestic and foreign currencies, respectively, and $P_{t}$ and $P_{t}{ }^{*}$ are the domestic and foreign price levels, respectively. $K_{t}$ is the domestic residents' average accumulated knowledge and experience of using foreign currency, which is a proxy for the general acceptability of foreign currency as a medium of exchange. We suppose that households take $K_{t}$ as given, but at an aggregate level, $K_{t}$ is endogenously determined. $\beta$ is a subjective discount factor. $B_{t}$ and $B_{t}{ }^{*}$ are nominal bonds denominated in domestic and foreign currencies, respectively. $i_{t-1}$ and $i_{t-1}{ }^{*}$ are nominal interest rates on bonds issued at the end of period $t-1$ to the end of period $t . Y_{t}$ is real income determined exogenously. Our utility function is specified as follows: (1) a household's preference can be represented by an additive separable function with respect to real consumption $C_{t}$ and currency index $X_{t},(2)$ the currency index $X_{t}$ is a constant elasticity of substitution (CES) technology in which elasticity of substitution is equal to $1 /(1+\varepsilon)$, and (3) the share of foreign currency in the utility function, $\delta$, is an increasing function of $K_{t}$, because foreign currency become more attractive as a medium of exchange as $K_{t}$ increases.

With these specifications and the assumption of purchasing power parity condition, Kumamoto and Kumamoto (2008) show the log-linearized relative money demand function as

$$
c s_{t}=(\overline{c s}+\bar{k})+[\eta /(1+\varepsilon)] k_{t}+[1 /(1+\varepsilon)][\bar{i} /(1+\bar{i})]\left(i_{t}-i_{t}{ }^{*}\right),
$$

where $\eta \equiv\left[\delta^{\prime}(\bar{K}) /\{\delta(\bar{K})(1-\delta(\bar{K}))\}\right] \bar{K}$. The lowercase letters denote natural logarithms except for nominal interest rates, and the upper bar denotes the steady-state value. $c s_{t}\left(\equiv m_{t}{ }^{*}+s_{t}-m_{t}\right)$ denotes relative money demand, which can be regarded as the degree of currency substitution, and $s_{t}$ is the natural logarithm of the nominal exchange rate in terms of the domestic currency. The interest rate differential $i_{t}-i_{t}{ }^{*}$ represents the usefulness of foreign currency as a store of value. If the interest rate differential increases, currency substitution increases as well because the domestic currency is expected to depreciate through the uncovered interest rate parity condition. Therefore, the cost of holding domestic currency increases. The knowledge of using foreign currency as a medium of exchange, $k_{t}$, proxies for its general acceptability and hence usefulness as a medium of exchange, capturing the ratchet effects of currency substitution. The implication is that domestic residents determine whether they should use domestic or foreign currency by comparing its usefulness as a store of value and a medium of exchange.

Moreover, Kumamoto and Kumamoto (2008) show that uncovered interest parity can be derived as

$$
i_{t}-i_{t}{ }^{*}=E_{t}\left[s_{t+1}\right]-s_{t}+v_{t}-v_{t}{ }^{*},
$$

where $v_{t}=-(1 / 2) \sigma_{p, t}^{2}, \sigma_{p, t}^{2} \equiv \operatorname{Var}_{t}\left[p_{t+1}\right]$, and $v_{t}{ }^{*}=-(1 / 2) \sigma_{p^{*}, t}^{2}, \sigma_{p^{*}, t}^{2} \equiv \operatorname{Var}_{t}\left[p_{t+1}{ }^{*}\right]$ and $\operatorname{Var}_{t}[\cdot]$ is a conditional variance operator based on information available at period $t$. (Note 5) The term $v_{t}-v_{t}{ }^{*}$ can be regarded as the risk premium. Note that if we insert equation (4) into (3), nominal exchange rate terms appear on both sides, which would cause endogenous bias. Therefore, we use the purchasing power parity condition in equation (4) to obtain

$$
i_{t}-i_{t}^{*}=E_{t}\left[p_{t+1}\right]-p_{t}-\left(E_{t}\left[p_{t+1}{ }^{*}\right]-p_{t}{ }^{*}\right)+v_{t}-v_{t}^{*} \text {. }
$$

Considering the possibility that currency substitution would react to the change in interest rate differential or the expected change in the nominal exchange rate (inflation rate differential) with some lags, we specify the following $\operatorname{ARDL}\left(p, q_{1}, q_{2}\right)$ model consisting of two equations:

$$
\begin{gathered}
c s_{t}=\mu+\sum_{i=1}^{p} \alpha_{i} c s_{t-i}+\sum_{j=0}^{q_{1}} \beta_{l j}\left(i_{t-j}-i_{t-j}{ }^{*}\right)+\sum_{j=0}^{q_{2}} \beta_{2 j} k_{t-j}+\varepsilon_{t}, \\
c s_{t}=\mu+\sum_{i=1}^{p} \alpha_{i} c s_{t-i}+\sum_{j=0}^{q_{1}} \beta_{l j}\left\{\left(E_{t-j}\left[p_{t-j+1}\right]-p_{t-j}\right)-\left(E_{t-j}\left[p_{t-j+1}{ }^{*}\right]-p_{t-j}^{*}\right)\right\}+\sum_{j=0}^{q_{2}} \beta_{2 j}\left(v_{t-j}-v_{t-j}^{*}\right)+\sum_{j=0}^{q_{3}} \beta_{3 j} k_{t-j}+\varepsilon_{t},
\end{gathered}
$$

where $\mu$ is a constant term and $\varepsilon$ is a disturbance term at $t$. (Note 6)

In this paper, we suppose that the maximum degree of currency substitution for the past one year represents the knowledge of using foreign currency as a medium of exchange at period $t$.

$$
k_{t}=\max _{j} c s_{j}, j=t-12, \cdots, t-1 .
$$

This assumption means that the knowledge of using foreign currency is proportional to the largest amount of the currency substitution in the past. However, the economy as a whole forgets how to use foreign currency in order to purchase goods as time passes.

To calculate $v_{t}$ and $v_{t}{ }^{*}$, we need to obtain the values of ${\sigma_{p, t}^{2}}^{2}$ and $\sigma_{p^{*}, t}^{2}$. In this paper, we estimate the series of $\sigma_{p, t}^{2}$ and 
$\sigma_{p^{*}, t}^{2}$ using the generalized autoregressive conditional heteroscedasticity (GARCH) model.

Assuming that $p_{t}$ follows the autoregressive integrated moving average (ARIMA) $(p, 1, q)$ process, $\Phi(L, p) \Delta p_{t}=\xi+$ $\Psi(L, p) \varepsilon_{p, t}, E_{t-1}\left[\Delta p_{t}\right] \sim N\left(0, h_{t}\right)$, we estimate the GARCH $\left(s_{1}, s_{2}\right)$ model, $h_{p, t}=\delta_{0}+\sum_{j=1}^{s_{1}} \delta_{j} \varepsilon_{p, t-j}^{2}+\sum_{j=1}^{s_{2}} \eta_{j} h_{p, t-j}$, for the residuals from the ARIMA model. The orders $p$ and $q$ of the ARIMA models are determined according to the Schwartz Bayesian information criterion (SBIC). We use the GARCH $(1,1)$ model as the lag length of the GARCH model. (Note 7) We adopt the same techniques for $p_{t}{ }^{*}$.

We rewrite equation (6) more compactly as

$$
A(L, p) c s_{t}=\mu+B_{1}\left(L, q_{1}\right)\left(i_{t}-i_{t}{ }^{*}\right)+B_{2}\left(L, q_{2}\right) k_{t}+\varepsilon_{t},
$$

where $L$ is a lag operator and $A(L, p)=1-\alpha_{1} L-\cdots-\alpha_{p} L^{p}$ and $B_{i}\left(L, q_{i}\right)=\beta_{i 0}+\beta_{i 1} L+\cdots+\beta_{i q} L^{q i},(i=1,2)$ are polynomials in the lag operator $L$. The distributed lag form of the ARDL model is

$$
\begin{gathered}
c s_{t}=\{1 / A(L, p)\} \mu+\left\{B_{I}\left(L, q_{1}\right) / A(L, p)\right\}\left(i_{t}-i_{t}{ }^{*}\right)+\left\{B_{2}\left(L, q_{2}\right) / A(L, p)\right\} k_{t}+\{1 / A(L, p)\} \varepsilon_{t} \\
=\{1 / A(L, p)\} \mu+\sum_{k=0}^{\infty} l_{k}\left(i_{t-k}-i_{t-k}{ }^{*}\right)+\sum_{l=0}^{\infty} v_{l} k_{t-l}+\sum_{n=0}^{\infty} \xi_{n} \varepsilon_{t-n} .
\end{gathered}
$$

The long-run effects for the response of $c s_{t}$ to a unit change in $i_{t}-i_{t}{ }^{*}$ and $k_{t}$ are $\sum_{k=0}^{\infty} l_{k}=B_{1}\left(L, q_{1}\right) / A(1, p)$ and $\sum_{l=0}^{\infty} v_{l}=$ $B_{2}\left(L, q_{2}\right) / A(1, p)$, respectively.

After some rearrangements, we get the error correction model (ECM) associated with the ARDL $\left(p, q_{1}, q_{2}\right)$ :

$$
\Delta c s_{t}=\beta_{10} \Delta\left(i_{t}-i_{t}{ }^{*}\right)+\beta_{20} \Delta k_{t}-\sum_{j=1}^{p-1} \alpha_{i}{ }^{*} \Delta c s_{t-j} \sum_{j=1}^{q_{1}-1} \beta_{l i}{ }^{*} \Delta\left(i_{t-j}-i_{t-j}{ }^{*}\right)-\sum_{j=1}^{q_{2}-1} \beta_{2 i}{ }^{*} \Delta\left(k_{t-j}\right)-A(1, p) E C_{t-1}+\varepsilon_{t},
$$

where $E C_{t}$ is the error correction term, defined by $\left.E C_{t}=c s_{t}-\{1 / A(1, p)\} \mu-\left\{B_{1}\left(1, q_{1}\right) / A(1, p)\right\}\left(i_{t}-i_{t}{ }^{*}\right)-B_{2}\left(1, q_{2}\right) / A(1, p)\right\} k_{t} . \alpha_{i}^{*}$ and $\beta_{i j}{ }^{*}$ are given by $\alpha_{1}{ }^{*}=\alpha_{p}+\alpha_{p-1}+\cdots+\alpha_{3}+\alpha_{2}, \alpha_{2}{ }^{*}=\alpha_{p}+\cdots+\alpha_{3}, \cdots, \alpha_{p-1}{ }^{*}=\alpha_{p}$ and $\beta_{i 1}{ }^{*}=\beta_{i q i}+\beta_{i q i-1}+\cdots+\beta_{i 3}+\beta_{i 2}, \beta_{i 2}{ }^{*}=\beta_{i q i}+$ $\beta_{i q t-1}+\cdots+\beta_{i 3}, \cdots, \beta_{i q t-1}{ }^{*}=\beta_{i q i}(i=1,2)$.

The main advantage of the ARDL model is that, as shown in Pesaran and Shin (1999), it can be applied irrespective of whether the underlying regressors are $I(0)$ or $I(1)$. This avoids the pretesting problems associated with standard cointegration analysis, which requires the classification of the variables into $I(0)$ and $I(1)$. (Note 8 )

The analytical procedure is as follows: First, we determine the lag length of equation (9) based on the Akaike information criterion (AIC) and estimate equation (6). Next, we estimate the long-run coefficients based on the above results. Finally, we obtain the short-run coefficients by estimating ECM (11).

The same argument can be applied for the transformation of equation (7).

\section{Data}

The appropriate data on the nominal balances of foreign currency represent the amount of foreign currency in circulation (holdings of nominal balances of foreign currency) plus demand deposits denominated in foreign currency. (Note 9) Unfortunately, data on foreign currency in circulation are difficult to collect. Therefore, we use the amount of demand deposits denominated in foreign currency as a proxy for nominal foreign currency balances. (Note 10) For consistency, we use data on demand deposits denominated in the domestic currency as a proxy for nominal domestic currency balances. The above data are collected from the respective central banks.

For the nominal interest rate, different authors use different data. For example, Mizen and Pentecost (1994) and Mongardini and Mueller (2000) use the treasury bill rate, and Akçay et al. (1997) use the interbank offered rate. Clements and Schwartz (1993), Bahmni-Oskooee and Karacal (2006), and Kumamoto and Kumamoto (2008) use the deposit rate for the nominal interest rate. Hence, this paper uses three measures of the nominal interest rate to confirm the robustness of the empirical result: (i) TB, defined as the average yield difference between each country's and the U.S.'s three-month treasury bills; (ii) IBOR, defined as the average monthly yield difference between each country's three-month interbank offered rate and the three-month London Interbank Offered Rate (LIBOR); and (iii) DR, defined as the three-month deposit rate difference between domestic and foreign currency deposits. (Note 11) For Poland, DR is defined as the three-month deposit rate difference between domestic and euro deposits. The above data are sourced from the IMF's International Financial Statistics (April 2014, CD- ROM) and the respective central banks.

To avoid endogenous bias as mentioned above, the expected change in the nominal exchange rate is proxied by monthly inflation rate differences, measured by the consumer price index differences between the respective countries (except for the Czech Republic, Hungary, and Poland) and the United States. For the three Eastern European countries, the monthly inflation rate differences are measured by the consumer price index difference between each country and the Euro area. Data shown above are sourced from the IMF's International Financial 
Statistics (April 2014, CD- ROM). The monthly-frequency data are seasonally adjusted.

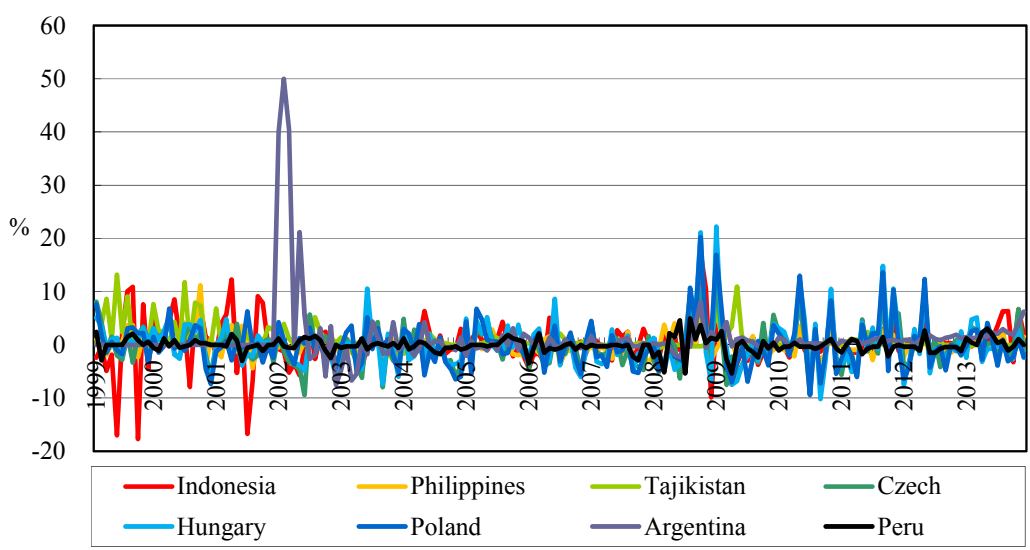

Figure 1. Depreciation rate of domestic currency vis-à-vis the U.S.

Data from IMF, International Financial Statistics, April 2014 (CD- ROM).

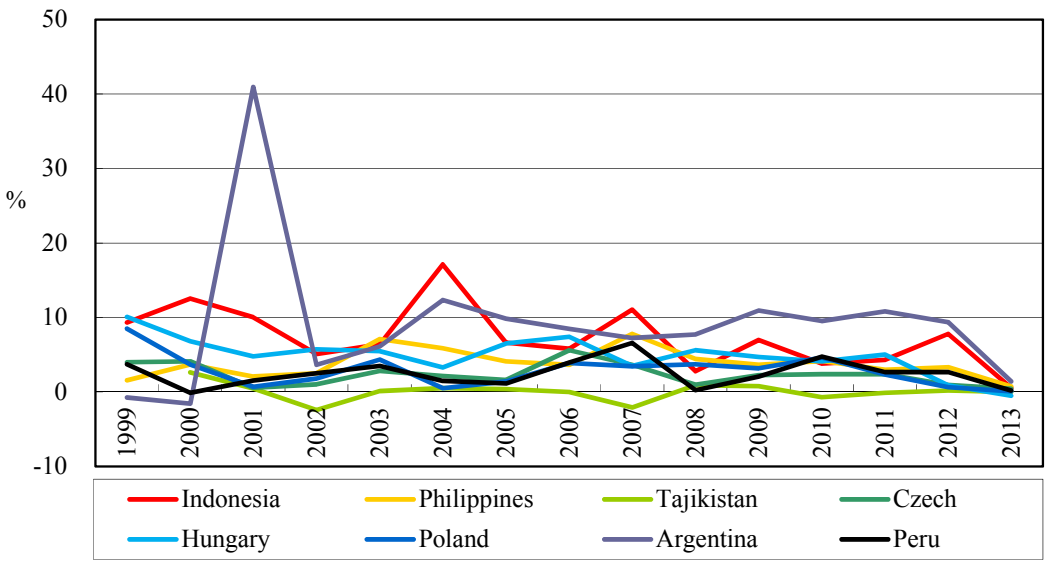

Figure 2. Inflation rate differential

Data from IMF, International Financial Statistics, April 2014 (CD- ROM).

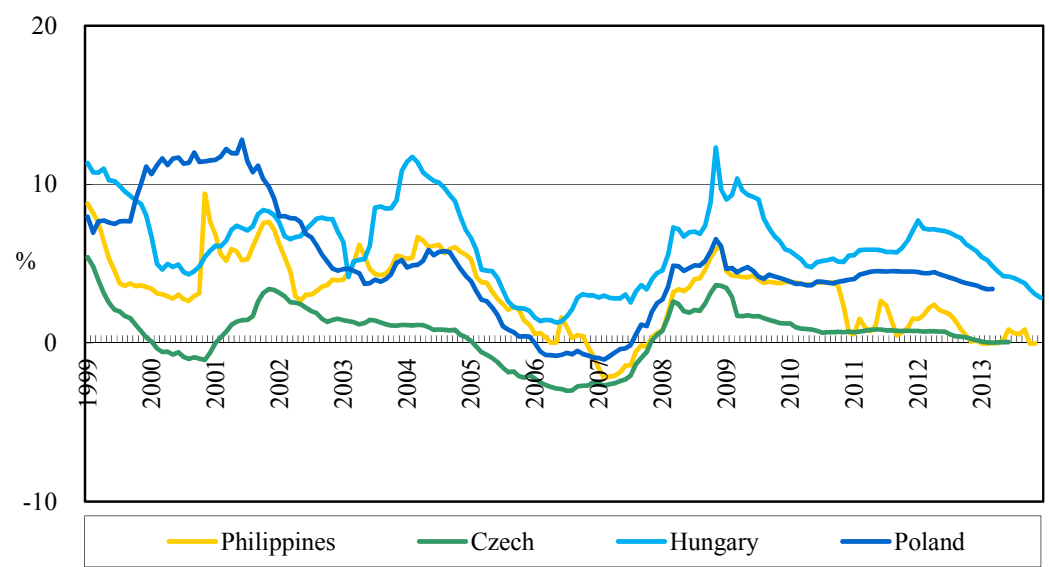

Figure 3. Nominal interest rate differential (TB)

TB = average yield difference between each country's and the U.S.'s three-month treasury bills. Data from IMF, International Financial Statistics, April 2014 (CD- ROM). 


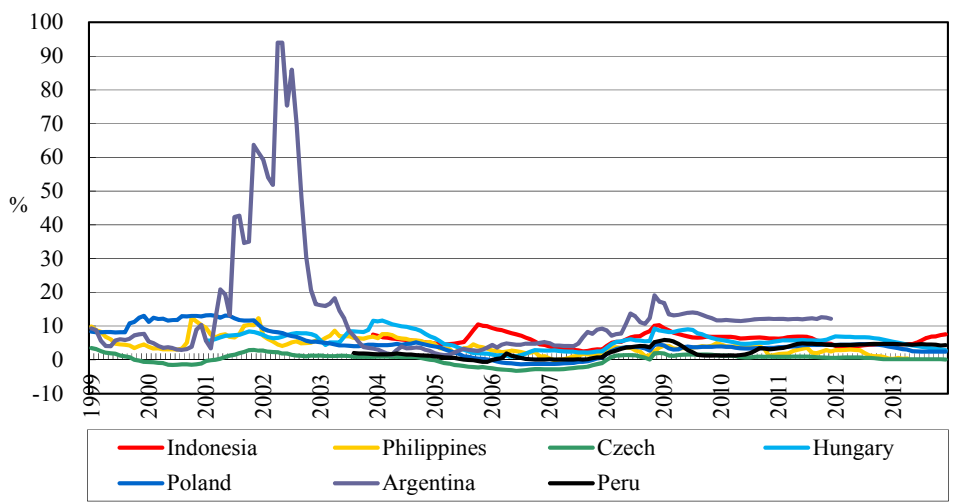

Figure 4. Nominal interest rate differential (IBOR)

IBOR $=$ average monthly yield difference between each country's three-month interbank offered rate and the three-month London Interbank Offered Rate. Data from IMF, International Financial Statistics, April 2014 (CDROM), Bank of Indonesia, Bangko Sentral ng Pilipinas, Czech National Bank, The Central Bank of Hungary, Polski Portal Finansowy, Banco Central de la República Argentina, Asociación de Bancos del Perú.

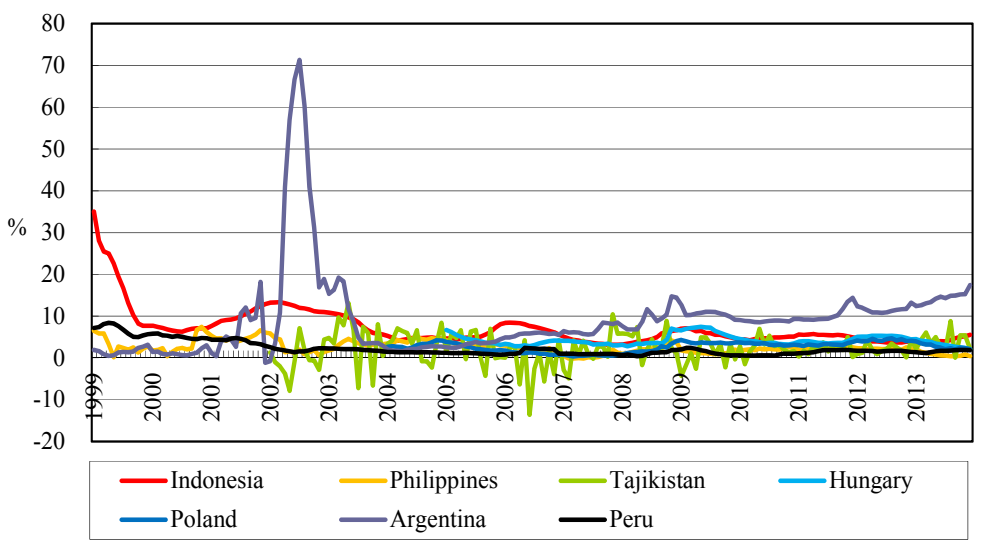

Figure 5. Nominal interest rate differential (DR)

$\mathrm{DR}=$ three-month deposit rate difference between domestic and foreign currency deposits. Data from IMF, International Financial Statistics, April 2014 (CD- ROM), National Bank of Tajikistan, The Central Bank of Hungary, Noradowy Bank Polski.

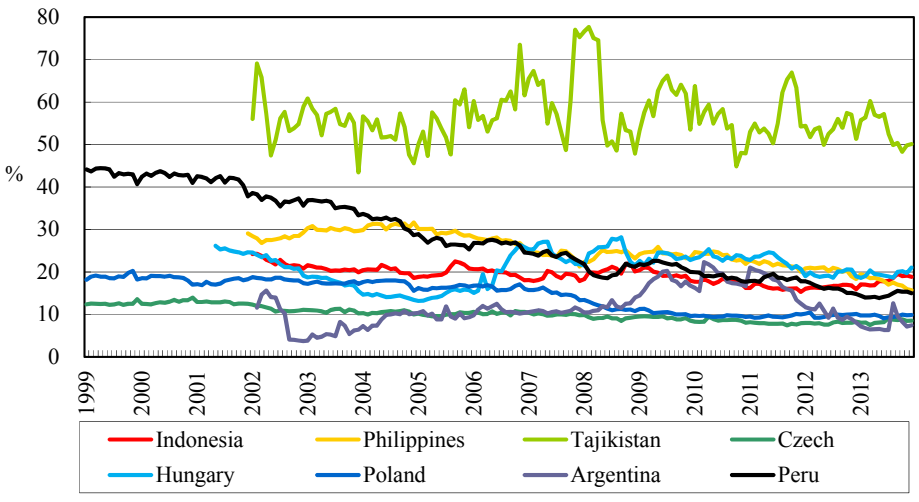

Figure 6. Degree of currency substitution

Degree of currency substitution is defined as the ratio of foreign currency deposits to total deposits. Data from Bank of Indonesia, Bangko Sentral ng Pilipinas, National Bank of Tajikistan, Czech National Bank, The Central Bank of Hungary, Noradowy Bank Polski, Banco Central de la República Argentina, Banco Central de Reserva del Peru. 
The data mentioned above are illustrated in Figures 1 to 6. As shown in Figure 6, the degree of currency substitution varies across countries. For example, it is below 15\% in the Czech Republic and Poland, and above $40 \%$ in Tajikistan.

\section{Empirical Findings}

\subsection{Empirical Results}

The empirical results are shown in Tables 1 and 2. (Note 12) The results in the tables are based on equation (6) (interest rate differential) and equation (7) (expected nominal exchange rate), respectively. They present the ECM representation of the short-run and implied long-run estimates. The optimal lag length for each variable is determined by AIC.

From Table 1, we see that the short-run coefficients of the interest rate differential, dIntdiff, have the expected sign and are statistically significant at the 10\% level in the Philippines (TB and IBOR), the Czech Republic (TB and IBOR), Hungary (TB), Poland (IBOR), Argentina (IBOR and DR), and Peru (DR). These results imply that the interest rate differential is a significant determinant of currency substitution in the short run. The ECM coefficient, $E C(-1)$, is negative and highly significant in all countries, reflecting the joint significance of the long-run coefficients. Consider a case in which the error correction term is positive. This occurs when the interest rate differential is lower than the degree of currency substitution implied by the long-run cointegration relationship. In this case, the negative coefficient of $E C(-1)$ indicates that currency substitution decreases in the next period. Hence, this implies that currency substitution decreases in response to a reduction in the interest rate differential. The F-statistic is highly significant, and the Durbin-Watson statistic does not indicate any sign of residual serial correlation.

The long-run coefficients of the interest rate differential, Intdiff, have the expected sign in all countries and are significant at the $10 \%$ level in the Philippines (TB and IBOR), the Czech Republic (TB and IBOR), Hungary (TB, IBOR, and DR), Poland (IBOR and DR), Argentina (IBOR and DR), and Peru (DR). Hence, these findings indicate that the interest rate differential is a significant determinant of currency substitution in all countries except Indonesia and Tajikistan. (Note 13) For Indonesia and Tajikistan, both the short- and long-run coefficients of the interest rate differential have the expected sign, but are insignificant.

More important, all short- and long-run coefficients of the ratchet variables, $d k$ and $k$, have the expected sign and are significant at the $1 \%$ level. This implies that as the past one-year peak value of currency substitution increases, both short- and long-run currency substitution increases as well. Therefore, currency substitution has a ratchet effect in all countries.

From Table 2, we see that $E C(-1)$ is negative and highly significant in Indonesia and Tajikistan, where the interest rate differentials are not significant. These results imply that the degree of currency substitution decreases in response to a reduction in the expected change in the nominal exchange rate and/or risk premium.

The long-run coefficients of the expected change in the nominal exchange rate, Exch, have the expected sign and are significant at the $10 \%$ level in both countries. The long-run coefficients of the risk premium $r p$ have the expected sign but are not significant in both countries. Thus, these findings indicate that the expected change in the nominal exchange rate is a significant currency substitution determinant.

Furthermore, we also see that both the short- and long-run coefficients of the ratchet variable have the expected sign and are significant at the $5 \%$ level.

\subsection{Discussion}

These empirical results indicate that variables representing the usefulness of a foreign currency, both as a medium of exchange and a store of value, are significant determinants of currency substitution. That is, the decline in the interest rate differential or the expected changes in the nominal exchange rate could reduce the degree of currency substitution. Thus, the central bank could have some impact on the degree of currency substitution by pursuing a monetary policy aimed at macroeconomic stabilization. However, all countries evidence strong ratchet effects. Therefore, even when the central bank decides to reduce currency substitution through macroeconomic stabilization in order to restore the usefulness of domestic currency as a store of value, currency substitution will not decrease rapidly. In other words, more powerful policies (i.e., de-dollarization or de-euroization) will need to be pursued over an extended period of time for further reduction of currency substitution. 
Table 1. Regression results

\begin{tabular}{|c|c|c|c|c|c|c|c|c|c|c|c|c|}
\hline \multirow[t]{2}{*}{ Variables } & \multicolumn{3}{|c|}{ Indonesia } & \multicolumn{3}{|c|}{ Philippines } & \multicolumn{3}{|c|}{ Tajikistan } & \multicolumn{3}{|c|}{ Czech } \\
\hline & TB & IBOR & DR & TB & IBOR & DR & TB & IBOR & DR & TB & IBOR & DR \\
\hline Intdiff & - & $\begin{array}{c}3.154 \\
(2.276)\end{array}$ & $\begin{array}{c}7.371 \\
(5.343)\end{array}$ & $\begin{array}{c}10.185 * * * \\
(1.262)\end{array}$ & $\begin{array}{c}14.827 * * * \\
(2.354)\end{array}$ & $\begin{array}{c}6.976 \\
(15.076)\end{array}$ & - & - & $\begin{array}{c}6.888 \\
(7.751)\end{array}$ & $\begin{array}{l}1.132 * \\
(0.674)\end{array}$ & $\begin{array}{l}1.513 * \\
(0.849)\end{array}$ & - \\
\hline Const. & - & $\begin{array}{l}-0.100 \\
(0.082)\end{array}$ & $\begin{array}{l}-0.105 \\
(0.086)\end{array}$ & $\begin{array}{c}-0.204 * * * \\
(0.040)\end{array}$ & $\begin{array}{c}-0.385 * * * \\
(0.069)\end{array}$ & $\begin{array}{l}-0.065 \\
(0.057)\end{array}$ & - & - & $\begin{array}{l}-0.076 \\
(0.062)\end{array}$ & $\begin{array}{c}0.060 \\
(0.027)\end{array}$ & $\begin{array}{l}0.053 * \\
(0.031)\end{array}$ & - \\
\hline$k$ & - & $\begin{array}{c}1.049 * * * \\
(0.126) \\
\end{array}$ & $\begin{array}{c}1.074 * * * \\
(0.126)\end{array}$ & $\begin{array}{c}0.945 * * * \\
(0.036) \\
\end{array}$ & $\begin{array}{c}0.829 * * * \\
(0.054)\end{array}$ & $\begin{array}{c}1.127 * * * \\
(0.108) \\
\end{array}$ & - & - & $\begin{array}{c}0.591 * * * \\
(0.097)\end{array}$ & $\begin{array}{c}0.953 * * * \\
(0.029)\end{array}$ & $\begin{array}{c}0.923 * * * \\
(0.034) \\
\end{array}$ & - \\
\hline \multicolumn{13}{|c|}{ Short-run Coefficients: Error Correction Representation } \\
\hline \multirow[t]{2}{*}{ Variables } & \multicolumn{3}{|c|}{ Indonesia } & \multicolumn{3}{|c|}{ Philippines } & \multicolumn{3}{|c|}{ Tajikistan } & \multicolumn{3}{|c|}{ Czech } \\
\hline & $\mathrm{TB}$ & IBOR & $\mathrm{DR}$ & $\mathrm{TB}$ & IBOR & $\mathrm{DR}$ & $\mathrm{TB}$ & IBOR & DR & $\mathrm{TB}$ & IBOR & DR \\
\hline$d C S(-1)$ & - & $\begin{array}{l}-0.235 \\
(0.115)\end{array}$ & $\begin{array}{l}0.179 * \\
(0.104)\end{array}$ & - & - & - & - & & $\begin{array}{c}0.248 * * \\
(0.103)\end{array}$ & - & - & - \\
\hline$d C S(-2)$ & - & $\begin{array}{c}-0.281 * * \\
(0.112)\end{array}$ & $\begin{array}{c}-0.174 * \\
(0.091)\end{array}$ & - & - & - & - & - & $\begin{array}{c}0.244^{* *} \\
(0.097)\end{array}$ & - & - & - \\
\hline$d C S(-3)$ & - & & $\begin{array}{l}0.152 * \\
(0.092)\end{array}$ & - & - & - & - & - & $\begin{array}{c}0.125 \\
(0.087)\end{array}$ & - & - & - \\
\hline dIntdiff & - & $\begin{array}{c}-3.549 * \\
(1.932)\end{array}$ & $\begin{array}{l}-0.393 \\
(9.147)\end{array}$ & $\begin{array}{c}3.717 * * * \\
(0.673)\end{array}$ & $\begin{array}{c}3.351 * * \\
(1.542)\end{array}$ & $\begin{array}{c}-9.472 * * \\
(4.748)\end{array}$ & - & - & $\begin{array}{c}4.211 \\
(4.669)\end{array}$ & $\begin{array}{l}0.458 * \\
(0.272)\end{array}$ & $\begin{array}{l}0.523 * \\
(0.289)\end{array}$ & - \\
\hline $\operatorname{dIntdiff}(-1)$ & - & $\begin{array}{c}-4.939 * * \\
(2.282)\end{array}$ & $\begin{array}{c}-20.343 \text { ** } \\
(8.910)\end{array}$ & - & $\begin{array}{c}-3.585 * * \\
(1.597)\end{array}$ & $\begin{array}{r}-2.870 \\
(5.054)\end{array}$ & - & - & - & - & - & - \\
\hline dIntdiff $(-2)$ & - & $\begin{array}{l}-0.292 \\
(2.109)\end{array}$ & - & - & - & $\begin{array}{c}-8.488 * \\
(4.719)\end{array}$ & - & - & - & - & - & - \\
\hline dIntdiff(-3) & - & $\begin{array}{l}-1.549 \\
(2.062)\end{array}$ & - & - & - & $\begin{array}{l}-3.795 \\
(4.880)\end{array}$ & - & - & - & - & - & - \\
\hline Const. & - & $\begin{array}{l}-0.028 \\
(0.024)\end{array}$ & $\begin{array}{l}-0.027 \\
(0.022)\end{array}$ & $\begin{array}{c}-0.074 * * * \\
(0.019)\end{array}$ & $\begin{array}{c}-0.110 * * * \\
(0.025)\end{array}$ & $\begin{array}{l}-0.011 \\
(0.011)\end{array}$ & - & - & $\begin{array}{l}-0.046 \\
(0.039)\end{array}$ & $\begin{array}{c}0.011 \\
(0.011)\end{array}$ & $\begin{array}{l}0.018 * \\
(0.011)\end{array}$ & - \\
\hline$d k$ & - & $\begin{array}{c}0.291 * * \\
(0.123)\end{array}$ & $\begin{array}{c}0.280 * * * \\
(0.094)\end{array}$ & $\begin{array}{c}0.345 * * * \\
(0.069)\end{array}$ & $\begin{array}{c}0.238 * * * \\
(0.057)\end{array}$ & $\begin{array}{c}0.198 * * \\
(0.078)\end{array}$ & - & - & $\begin{array}{c}0.362 * * * \\
(0.093)\end{array}$ & $\begin{array}{c}0.385 * * * \\
(0.066)\end{array}$ & $\begin{array}{c}0.319 * * * \\
(0.060)\end{array}$ & - \\
\hline$E C(-1)$ & - & $\begin{array}{c}-0.277^{* *} \\
(0.106) \\
\end{array}$ & $\begin{array}{c}-0.261 * * * \\
(0.085) \\
\end{array}$ & $\begin{array}{c}-0.365 * * * \\
(0.071) \\
\end{array}$ & $\begin{array}{c}-0.286 * * * \\
(0.062) \\
\end{array}$ & $\begin{array}{c}-0.176 * * \\
(0.070) \\
\end{array}$ & - & - & $\begin{array}{c}-0.611 * * * \\
(0.109) \\
\end{array}$ & $\begin{array}{c}-0.404 * * * \\
(0.068) \\
\end{array}$ & $\begin{array}{c}-0.345 * * * \\
(0.062) \\
\end{array}$ & - \\
\hline SEE & - & 0.016 & 0.017 & 0.024 & 0.025 & 0.025 & - & - & 0.175 & 0.014 & 0.014 & - \\
\hline R-squared & - & 0.292 & 0.218 & 0.305 & 0.211 & 0.211 & - & - & 0.228 & 0.253 & 0.217 & - \\
\hline DW-statistics & - & 2.005 & 1.951 & 1.966 & 2.042 & 1.981 & - & - & 1.963 & 1.878 & 1.890 & - \\
\hline F-statistic & - & 6.745 & 3.926 & 6.460 & 8.284 & 8.284 & - & - & 6.556 & 6.690 & 5.713 & - \\
\hline sample period & - & $\begin{array}{c}2003 \mathrm{M} 12 \\
-2013 \mathrm{M} 12 \\
\end{array}$ & $\begin{array}{c}2002 \mathrm{M} 1 \\
-2013 \mathrm{M} 12 \\
\end{array}$ & $\begin{array}{c}2001 \mathrm{M} 12 \\
-2013 \mathrm{M} 11 \\
\end{array}$ & $\begin{array}{l}2001 \mathrm{M} 12 \\
-2013 \mathrm{M} 4 \\
\end{array}$ & $\begin{array}{c}2001 \mathrm{M} 12 \\
-2013 \mathrm{M} 12 \\
\end{array}$ & - & - & $\begin{array}{c}\text { 2002M1 } \\
-2013 \mathrm{M} 12 \\
\end{array}$ & $\begin{array}{c}\text { 1999M1 } \\
-2013 \mathrm{M} 6 \\
\end{array}$ & $\begin{array}{c}\text { 1999M1 } \\
-2013 \mathrm{M} 12 \\
\end{array}$ & - \\
\hline \multicolumn{13}{|c|}{ Estimated Long-run Coefficients } \\
\hline \multirow[t]{2}{*}{ Variables } & \multicolumn{3}{|c|}{ Hungary } & \multicolumn{3}{|c|}{ Poland } & \multicolumn{3}{|c|}{ Argentina } & \multicolumn{3}{|c|}{ Peru } \\
\hline & TB & IBOR & $\mathrm{DR}$ & TB & IBOR & $\mathrm{DR}$ & TB & IBOR & DR & TB & IBOR & $\mathrm{DR}$ \\
\hline Intdiff & $\begin{array}{c}16.609 * * \\
(6.494)\end{array}$ & $\begin{array}{c}15.524 * * * \\
(4.926)\end{array}$ & $\begin{array}{c}26.238 * * * \\
(9.786)\end{array}$ & $\begin{array}{c}0.022 \\
(0.695)\end{array}$ & $\begin{array}{l}0.382 * \\
(0.204)\end{array}$ & $\begin{array}{c}2.198 * * * \\
(0.878)\end{array}$ & - & $\begin{array}{c}2.255 * * \\
(1.093)\end{array}$ & $\begin{array}{c}11.591 * * * \\
(4.185)\end{array}$ & - & $\begin{array}{c}3.258 \\
(9.981)\end{array}$ & $\begin{array}{c}120.010 * \\
(71.753)\end{array}$ \\
\hline Const. & $\begin{array}{l}-0.171 \\
(0.128)\end{array}$ & $\begin{array}{c}-0.129 \\
(0.099)\end{array}$ & $\begin{array}{c}-0.206 * * \\
(0.091)\end{array}$ & $\begin{array}{c}-0.126 \\
(0.119)\end{array}$ & $\begin{array}{l}-0.007 \\
(0.103)\end{array}$ & $\begin{array}{l}-0.008 \\
(0.012)\end{array}$ & - & $\begin{array}{c}0.066 \\
(0.111)\end{array}$ & $\begin{array}{c}0.034 \\
(0.100)\end{array}$ & - & $\begin{array}{c}-0.120 \\
(0.185)\end{array}$ & $\begin{array}{c}-0.537^{*} \\
(0.290)\end{array}$ \\
\hline$k$ & $\begin{array}{c}0.731 * * * \\
(0.218)\end{array}$ & $\begin{array}{c}0.698 * * * \\
(0.181)\end{array}$ & $\begin{array}{c}0.841^{* * *} \\
(0.069) \\
\end{array}$ & $\begin{array}{c}1.192 * * * \\
(0.189)\end{array}$ & $\begin{array}{c}0.991 * * * \\
(0.012) \\
\end{array}$ & $\begin{array}{c}1.011 * * * \\
(0.017)\end{array}$ & - & $\begin{array}{c}0.716^{* * *} \\
(0.119) \\
\end{array}$ & $\begin{array}{c}0.748^{* * *} \\
(0.104) \\
\end{array}$ & - & $\begin{array}{c}1.027 * * * \\
(0.190) \\
\end{array}$ & $\begin{array}{c}0.888 * * * \\
(0.130)\end{array}$ \\
\hline \multicolumn{13}{|c|}{ Short-run Coefficients: Error Correction Representation } \\
\hline \multirow[t]{2}{*}{ Variables } & & Hungary & & & Poland & & & Argentina & & & Peru & \\
\hline & TB & IBOR & DR & TB & IBOR & DR & TB & IBOR & DR & TB & IBOR & DR \\
\hline$d C S(-1)$ & $\begin{array}{l}-0.063 \\
(0.092)\end{array}$ & $\begin{array}{l}-0.012 \\
(0.094)\end{array}$ & $\begin{array}{c}0.057 \\
(0.100)\end{array}$ & - & $\begin{array}{c}0.267 * * * \\
(0.080)\end{array}$ & $\begin{array}{l}0.230 * * \\
(0.0890)\end{array}$ & - & $\begin{array}{c}-0.174 * \\
(0.098)\end{array}$ & $\begin{array}{l}-0.125 \\
(0.086)\end{array}$ & - & $\begin{array}{c}0.336 * * * \\
(0.107)\end{array}$ & $\begin{array}{c}0.209 * * * \\
(0.079)\end{array}$ \\
\hline$d C S(-2)$ & $\begin{array}{c}0.103 \\
(0.093)\end{array}$ & $\begin{array}{c}0.076 \\
(0.092)\end{array}$ & $\begin{array}{c}0.155 \\
(0.098)\end{array}$ & - & $\begin{array}{c}0.083 \\
(0.078)\end{array}$ & - & - & - & - & - & $\begin{array}{c}0.110 \\
(0.113)\end{array}$ & - \\
\hline$d C S(-3)$ & $\begin{array}{c}0.242 * * * \\
(0.090)\end{array}$ & $\begin{array}{c}0.228 * * \\
(0.090)\end{array}$ & $\begin{array}{c}0.316 * * * \\
(0.094)\end{array}$ & - & $\begin{array}{c}0.186 * * \\
(0.073)\end{array}$ & - & - & - & - & - & $\begin{array}{l}0.232 * \\
(0.113)\end{array}$ & - \\
\hline dIntdiff & $\begin{array}{l}3.152 * \\
(1.821)\end{array}$ & $\begin{array}{c}2.700 \\
(2.147)\end{array}$ & $\begin{array}{c}-12.105^{* *} \\
(4.735)\end{array}$ & $\begin{array}{c}0.006 \\
(0.179)\end{array}$ & $\begin{array}{l}1.551 * \\
(0.885)\end{array}$ & $\begin{array}{c}0.408 \\
(1.742)\end{array}$ & - & $\begin{array}{l}1.631 * \\
(0.856)\end{array}$ & $\begin{array}{c}5.335 * * * \\
(2.459)\end{array}$ & - & $\begin{array}{l}-4.793 \\
(3.300)\end{array}$ & $\begin{array}{c}36.456 * * * \\
(10.928)\end{array}$ \\
\hline $\operatorname{dIntdiff(-1)}$ & $\begin{array}{c}2.466 \\
(1.830)\end{array}$ & $\begin{array}{l}-0.456 \\
(2.202)\end{array}$ & - & - & - & $\begin{array}{c}1.019 \\
(1.706)\end{array}$ & - & $\begin{array}{c}-0.982 * * \\
(0.473)\end{array}$ & - & - & - & $\begin{array}{c}8.515 \\
(11.458)\end{array}$ \\
\hline $\operatorname{dIntdiff(-2)}$ & $\begin{array}{c}-4.359 * * \\
(1.811)\end{array}$ & $\begin{array}{c}-5.833 * * * \\
(2.193)\end{array}$ & - & - & - & $\begin{array}{c}0.944 \\
(1.708)\end{array}$ & - & - & - & - & - & $\begin{array}{l}-14.207 \\
(11.052)\end{array}$ \\
\hline $\operatorname{dIntdiff(-3)}$ & $\begin{array}{l}-2.194 \\
(1.835)\end{array}$ & - & - & - & - & $\begin{array}{c}4.282 * * \\
(1.765)\end{array}$ & - & - & - & - & - & $\begin{array}{c}27.510 * * * \\
(10.178)\end{array}$ \\
\hline Const. & $\begin{array}{l}-0.020 \\
(0.016)\end{array}$ & $\begin{array}{l}-0.019 \\
(0.016)\end{array}$ & $\begin{array}{c}-0.095 * * \\
(0.044)\end{array}$ & $\begin{array}{l}-0.033 \\
(0.029)\end{array}$ & $\begin{array}{l}-0.003 \\
(0.005)\end{array}$ & $\begin{array}{l}-0.005 \\
(0.007)\end{array}$ & - & $\begin{array}{c}0.015 \\
(0.026)\end{array}$ & $\begin{array}{c}0.009 \\
(0.026)\end{array}$ & - & $\begin{array}{c}-0.013 \\
(0.051)\end{array}$ & $\begin{array}{c}-0.024 * * \\
(0.009)\end{array}$ \\
\hline$d k$ & $\begin{array}{l}0.086 * \\
(0.050)\end{array}$ & $\begin{array}{l}0.102 * \\
(0.052)\end{array}$ & $\begin{array}{c}0.388 * * * \\
(0.088)\end{array}$ & $\begin{array}{c}0.307 * * * \\
(0.090)\end{array}$ & $\begin{array}{c}0.515 * * * \\
(0.082)\end{array}$ & $\begin{array}{c}0.587 * * * \\
(0.095)\end{array}$ & - & $\begin{array}{c}0.167 * * \\
(0.068)\end{array}$ & $\begin{array}{c}0.196 * * * \\
(0.067)\end{array}$ & - & $\begin{array}{l}0.115 * \\
(0.051)\end{array}$ & $\begin{array}{c}0.199 * * * \\
(0.051)\end{array}$ \\
\hline$E C(-1)$ & $\begin{array}{c}-0.117 * * \\
(0.046)\end{array}$ & $\begin{array}{c}-0.146 * * * \\
(0.050)\end{array}$ & $\begin{array}{c}-0.461 * * * \\
(0.089)\end{array}$ & $\begin{array}{c}-0.258 * * * \\
(0.080)\end{array}$ & $\begin{array}{c}-0.519^{* * *} \\
(0.082)\end{array}$ & $\begin{array}{c}-0.580 * * * \\
(0.093)\end{array}$ & - & $\begin{array}{c}-0.234 * * * \\
(0.072)\end{array}$ & $\begin{array}{c}-0.263 * * * \\
(0.069)\end{array}$ & - & $\begin{array}{c}-0.112 * * \\
(0.050)\end{array}$ & $\begin{array}{c}-0.209 * * * \\
(0.052)\end{array}$ \\
\hline$S E E$ & 0.053 & 0.054 & 0.060 & 0.013 & 0.012 & 0.012 & - & 0.063 & 0.069 & - & 0.016 & 0.017 \\
\hline R-squared & 0.278 & 0.224 & 0.285 & 0.222 & 0.247 & 0.313 & - & 0.318 & 0.286 & - & 0.223 & 0.293 \\
\hline DW-statistics & 1.913 & 2.030 & 1.951 & 1.892 & 1.903 & 2.027 & - & 1.918 & 1.935 & - & 1.945 & 1.999 \\
\hline F-statistic & 4.661 & 4.323 & 4.643 & 5.529 & 6.711 & 6.963 & - & 10.142 & 13.423 & - & 4.507 & 8.682 \\
\hline sample period & $\begin{array}{c}2001 \mathrm{M} 5 \\
-2013 \mathrm{M} 12\end{array}$ & $\begin{array}{c}\text { 2001M5 } \\
-2013 \mathrm{M} 12\end{array}$ & $\begin{array}{c}2005 \mathrm{M} 1 \\
-2013 \mathrm{M} 12\end{array}$ & $\begin{array}{c}\text { 1999M1 } \\
-2013 \mathrm{M} 3\end{array}$ & $\begin{array}{c}\text { 1999M1 } \\
-2013 \mathrm{M} 12\end{array}$ & $\begin{array}{c}2004 \mathrm{M} 1 \\
-2013 \mathrm{M} 12\end{array}$ & - & $\begin{array}{c}2002 \mathrm{M} 1 \\
-2011 \mathrm{M} 12\end{array}$ & $\begin{array}{c}2002 \mathrm{M} 1 \\
-2013 \mathrm{M} 12\end{array}$ & - & $\begin{array}{c}2003 \mathrm{M} 8 \\
-2013 \mathrm{M} 12\end{array}$ & $\begin{array}{c}1999 \mathrm{M} 1 \\
-2013 \mathrm{M} 12\end{array}$ \\
\hline
\end{tabular}

Notes: ***, **, and * denote significance at the $1 \%, 5 \%$, and $10 \%$ levels, respectively. Standard errors are in parentheses. 
Table 2. Extended regression results

\begin{tabular}{|c|c|c|c|c|c|c|c|c|}
\hline Variables & Indonesia & Philippines & Tajikistan & Czech & Hungary & Poland & Argentina & Peru \\
\hline Exch & $\begin{array}{c}2.150 * * \\
(1.048)\end{array}$ & $\begin{array}{c}5.342 * * \\
(2.254)\end{array}$ & $\begin{array}{c}8.179 * * \\
(3.292)\end{array}$ & $\begin{array}{c}4.002 * * \\
(1.825)\end{array}$ & $\begin{array}{c}0.275 \\
(1.711)\end{array}$ & $\begin{array}{l}-0.065 \\
(0.057)\end{array}$ & $\begin{array}{c}0.232 \\
(2.209)\end{array}$ & $\begin{array}{c}0.157 \\
(0.151)\end{array}$ \\
\hline$r p$ & $\begin{array}{c}832.785 \\
(763.466)\end{array}$ & $\begin{array}{l}-3100.9 \\
(2785.8)\end{array}$ & $\begin{array}{c}56.374 \\
(421.633)\end{array}$ & $\begin{array}{c}1631.0 \\
(1252.5)\end{array}$ & $\begin{array}{c}1870.5 \\
(5866.4)\end{array}$ & $\begin{array}{c}339.040 \\
(691.071)\end{array}$ & $\begin{array}{c}593.709 * * \\
(252.529)\end{array}$ & $\begin{array}{c}3862.8 * * * \\
(435.867)\end{array}$ \\
\hline Const. & $\begin{array}{c}-0.733 * * \\
(0.305)\end{array}$ & $\begin{array}{c}0.032 \\
(0.188)\end{array}$ & $\begin{array}{l}-0.082 \\
(0.064)\end{array}$ & $\begin{array}{l}-0.112 \\
(0.203)\end{array}$ & $\begin{array}{c}-0.364 * \\
(0.210)\end{array}$ & $\begin{array}{c}-0.020 * \\
(0.011)\end{array}$ & $\begin{array}{l}0.342 * \\
(0.194)\end{array}$ & $\begin{array}{c}-0.020 * * * \\
(0.003)\end{array}$ \\
\hline$k$ & $\begin{array}{c}0.557 * * * \\
(0.210)\end{array}$ & $\begin{array}{c}1.104 * * * \\
(0.116) \\
\end{array}$ & $\begin{array}{c}0.569 * * * \\
(0.095)\end{array}$ & $\begin{array}{c}1.025 * * * \\
(0.280) \\
\end{array}$ & $\begin{array}{c}0.824 * * * \\
(0.171) \\
\end{array}$ & $\begin{array}{c}1.005 * * * \\
(0.015)\end{array}$ & $\begin{array}{c}0.577 * * * \\
(0.172)\end{array}$ & $\begin{array}{c}1.008 * * * \\
(0.006)\end{array}$ \\
\hline \multicolumn{9}{|c|}{ hort-run Coefficients: Error Correction Representation } \\
\hline Variables & Indonesia & Philippines & Tajikistan & Czech & Hungary & Poland & Argentina & Peru \\
\hline$d C S(-1)$ & $\begin{array}{c}0.020 \\
(0.090)\end{array}$ & $\begin{array}{c}-0.163 * \\
(0.091)\end{array}$ & $\begin{array}{c}0.132 \\
(0.105)\end{array}$ & $\begin{array}{c}-0.212 * * * \\
(0.079)\end{array}$ & $\begin{array}{c}0.108 \\
(0.092)\end{array}$ & $\begin{array}{l}0.215^{*} \\
(0.082)\end{array}$ & $\begin{array}{c}-0.258 * * * \\
(0.095)\end{array}$ & $\begin{array}{c}0.313 * * * \\
(0.066)\end{array}$ \\
\hline$d C S(-2)$ & $\begin{array}{c}-0.229 * * \\
(0.091)\end{array}$ & - & $\begin{array}{c}0.284 * * * \\
(0.099)\end{array}$ & - & $\begin{array}{c}0.122 \\
(0.091)\end{array}$ & $\begin{array}{c}0.089 \\
(0.078)\end{array}$ & $\begin{array}{l}-0.133 \\
(0.086)\end{array}$ & $\begin{array}{c}0.166 * * \\
(0.068)\end{array}$ \\
\hline$d C S(-3)$ & - & - & $\begin{array}{l}0.152 * \\
(0.091)\end{array}$ & - & $\begin{array}{c}0.284 * * * \\
(0.086)\end{array}$ & $\begin{array}{l}0.1 \\
(0.0\end{array}$ & - & $\begin{array}{c}0.333 * * * \\
(0.066)\end{array}$ \\
\hline dExch & $\begin{array}{c}0.350 * * * \\
(0.086)\end{array}$ & $\begin{array}{c}0.629 * * * \\
(0.134)\end{array}$ & $\begin{array}{c}0.709 \\
(1.293)\end{array}$ & $\begin{array}{c}0.004 \\
(0.061)\end{array}$ & $\begin{array}{c}0.112 \\
(0.097)\end{array}$ & $\begin{array}{l}0.095 * \\
(0.050)\end{array}$ & $\begin{array}{c}0.095 \\
(0.289)\end{array}$ & $\begin{array}{c}0.097 \\
(0.092)\end{array}$ \\
\hline$d \operatorname{Exch}(-1)$ & $\begin{array}{c}-0.320 * * \\
(0.113)\end{array}$ & - & - & $\begin{array}{c}-0.693 * * * \\
(0.135)\end{array}$ & $\begin{array}{l}-0.187 \\
(0.176)\end{array}$ & $\begin{array}{c}0.048 \\
(0.042)\end{array}$ & - & - \\
\hline$d \operatorname{Exch}(-2)$ & $\begin{array}{c}-0.171 * \\
(0.088)\end{array}$ & - & - & $\begin{array}{c}-0.505 * * * \\
(0.119)\end{array}$ & $\begin{array}{r}-0.30 \\
(0.1\end{array}$ & $\begin{array}{l}0.5 \\
(0.0\end{array}$ & - & - \\
\hline$d \operatorname{Exch}(-3)$ & $\begin{array}{l}-0.108 \\
(0.153)\end{array}$ & - & - & $\begin{array}{c}-0.343 * * * \\
(0.094)\end{array}$ & $\begin{array}{c}-0.205 * * \\
(0.101)\end{array}$ & $\begin{array}{c}0.070 * * * \\
(0.024)\end{array}$ & - & - \\
\hline$d r p$ & $\begin{array}{c}96.376 \\
(79.805)\end{array}$ & $\begin{array}{l}-364.849 \\
(341.343)\end{array}$ & $\begin{array}{c}22.793 \\
(170.293)\end{array}$ & $\begin{array}{l}285.804 * \\
(161.355)\end{array}$ & $\begin{array}{c}244.672 \\
(743.941)\end{array}$ & $\begin{array}{c}150.283 \\
(308.786)\end{array}$ & $\begin{array}{c}17.531 \\
(20.221)\end{array}$ & $\begin{array}{c}526.687 \\
(406.696)\end{array}$ \\
\hline$d r p(-1)$ & $\begin{array}{c}132.696 * \\
(76.390)\end{array}$ & - & - & - & - & - & $\begin{array}{c}-100.054 * * * \\
(19.386)\end{array}$ & $\begin{array}{c}-1503.3 * * * \\
(425.056)\end{array}$ \\
\hline$d r p(-2)$ & - & - & - & - & - & - & $\begin{array}{c}-85.096 * * * \\
(17.894)\end{array}$ & $\begin{array}{c}-1902.6 * * * \\
(424.810)\end{array}$ \\
\hline$d r p(-3)$ & - & - & - & - & - & - & $\begin{array}{c}-80.910 * * * \\
(16.342)\end{array}$ & - \\
\hline Const. & $\begin{array}{c}-0.080 * * \\
(0.033)\end{array}$ & $\begin{array}{c}0.002 \\
(0.013)\end{array}$ & $\begin{array}{l}-0.044 \\
(0.043)\end{array}$ & $\begin{array}{l}-0.015 \\
(0.028)\end{array}$ & $\begin{array}{c}-0.048 * \\
(0.026)\end{array}$ & $\begin{array}{c}-0.009 * \\
(0.005)\end{array}$ & $\begin{array}{c}0.052 * * \\
(0.025)\end{array}$ & $\begin{array}{c}-0.012 * * * \\
(0.003) 4\end{array}$ \\
\hline$d k$ & $\begin{array}{c}0.183 * * \\
(0.075)\end{array}$ & $\begin{array}{c}0.130 * * \\
(0.052)\end{array}$ & $\begin{array}{c}0.358 * * * \\
(0.061)\end{array}$ & $\begin{array}{c}0.135 * * \\
(0.053)\end{array}$ & $\begin{array}{c}0.191 * * * \\
(0.068)\end{array}$ & $\begin{array}{c}0.440 * * * \\
(0.083)\end{array}$ & $\begin{array}{c}0.149 * * \\
(0.059)\end{array}$ & $\begin{array}{c}0.622 * * * \\
(0.068)\end{array}$ \\
\hline$E C(-1)$ & $\begin{array}{c}-0.245 * * * \\
(0.082)\end{array}$ & $\begin{array}{c}-0.118 * * \\
(0.049)\end{array}$ & $\begin{array}{c}-0.629 * * * \\
(0.112)\end{array}$ & $\begin{array}{c}-0.136 * * \\
(0.053)\end{array}$ & $\begin{array}{c}-0.215 * * * \\
(0.067)\end{array}$ & $\begin{array}{c}-0.438 * * * \\
(0.082)\end{array}$ & $\begin{array}{c}-0.245 * * * \\
(0.060)\end{array}$ & $\begin{array}{c}-0.617 * * * \\
(0.067)\end{array}$ \\
\hline$S E E$ & 0.028 & 0.025 & 0.166 & 0.029 & 0.055 & 0.013 & 0.066 & 0.171 \\
\hline R-squared & 0.271 & 0.185 & 0.316 & 0.231 & 0.192 & 0.228 & 0.357 & 0.280 \\
\hline DW-statistics & 1.938 & 2.059 & 1.982 & 1.961 & 1.978 & 1.889 & 1.908 & 2.055 \\
\hline F-statistic & 6.048 & 5.576 & 6.573 & 3.921 & 3.238 & 5.289 & 9.030 & 7.237 \\
\hline sample period & $\begin{array}{c}2002 \mathrm{M} 1 \\
-2013 \mathrm{M} 12\end{array}$ & $\begin{array}{c}2001 \mathrm{M} 12 \\
-2013 \mathrm{M} 12\end{array}$ & $\begin{array}{c}2002 \mathrm{M} 1 \\
-2013 \mathrm{M} 12\end{array}$ & $\begin{array}{c}\text { 1999M1 } \\
-2013 \mathrm{M} 12\end{array}$ & $\begin{array}{c}2001 \mathrm{M} 5 \\
-2013 \mathrm{M} 12\end{array}$ & $\begin{array}{c}\text { 1999M1 } \\
-2013 \mathrm{M} 12\end{array}$ & $\begin{array}{c}2002 \mathrm{M} 1 \\
-2013 \mathrm{M} 12\end{array}$ & $\begin{array}{c}1999 \mathrm{M} 1 \\
-2013 \mathrm{M} 12\end{array}$ \\
\hline
\end{tabular}

Notes: $* * *, * *$, and $*$ denote significance at the $1 \%, 5 \%$, and $10 \%$ levels, respectively. Standard errors are in parentheses.

\section{Conclusion}

In this paper, we empirically investigated recent currency substitution experiences. In particular, we focused on the determinants of currency substitution, namely, the factors representing the usefulness of foreign currency, both as a medium of exchange and a store of value.

In the analysis, we estimated an equation from the agent's utility maximization problem and introduced the exchange rate risk premium as an alternative determinant, considering the forward premium puzzle.

Empirical results show that the variables representing the usefulness of foreign currency, both as a medium of exchange and a store of value, are significant determinants of currency substitution. They indicated that the central bank could have some impact on the degree of currency substitution by pursuing a monetary policy aimed at macroeconomic stabilization. However, all countries evidence strong ratchet effects. Therefore, even when the central bank decides to reduce currency substitution through macroeconomic stabilization in order to restore the usefulness of the domestic currency as a store of value, currency substitution will not decrease rapidly. In other words, more powerful policies (i.e., de-dollarization or de-euroization) will need to be pursued over an extended period of time for further reduction of currency substitution. 
Note that these results should be treated with caution for the following reasons. First, as shown by the R-squared statistics, the currency substitution model used here can only explain about 19 to $36 \%$ of the currency substitution phenomenon. Second, the currency substitution measure should include foreign currency in circulation. However, such data are not available, so the currency substitution measure used in this paper is incomplete. Other factors, too, explain the currency substitution phenomenon, and a more accurate measure of currency substitution will therefore need to be incorporated in the model to conclude that monetary policy or exchange rate policy could indeed be effective in reducing currency substitution. These tasks are our future research direction.

\section{Acknowledgements}

The author thanks the anonymous referee and the Associate Editor for helpful comments and suggestions. This research is financially supported by a Grant-in-Aid for Scientific Research from the Japan Society for the Promotion of Science (B) no. 24730265.

\section{References}

Adam, C., Goujon, M., \& Guillaumont, J. S. (2004). The transactions demand for money in the presence of currency substitution: Evidence from Vietnam. Applied Economics, 36(13), 1461-1470. http://dx.doi.org/10.1080/000368404200029839

Akçay, O. C., Alper, C. E., \& Karasulu. M. (1997). Currency substitution and exchange rate instability: The Turkish case. European Economic Review, 41(3-5), 827-835. http://dx.doi.org/10.1016/S0014-2921(97)00040-8

Asociación de Bancos del Perú. Retrieved from https://www.mef.gob.pe/

Bahmni-Oskooee, M., \& Karacal, M. (2006). The demand for money in Turkey and currency substitution. Applied Economics Letters, 13(10), 635-642. http://dx.doi.org/10.1080/13504850500358819

Banco Central de la República Argentina. Retrieved from http://www.bcra.gov.ar/index_i.htm

Banco Central de Reserva del Peru. Retrieved from http://www.bcrp.gob.pe/home.html

Bangko Sentral ng Pilipinas. Retrieved from http://www.bsp.gov.ph/

Bank of Indonesia. Retrieved from http://www.bi.go.id/en/Default.aspx

Bolleslev, T. (1986). Generalized autoregressive conditional heteroscedasticity. Journal of Econometrics, 31(3), 307-327. http://dx.doi.org/10.1016/0304-4076(86)90063-1

Chakraborty, A., \& Evans, G. W. (2008). Can perpetual learning explain the forward-premium puzzle? Journal of Monetary Economics, 55(3), 477-490. http://dx.doi.org/10.1016/j.jmoneco.2008.03.002

Clements, B., \& Schwartz, G. (1993). Currency substitution: The recent experience of Bolivia. World Development, 21(11), 1883-1893. http://dx.doi.org/10.1016/0305-750X(93)90089-R

Czech National Bank. Retrieved from http://www.cnb.cz/en/index.html

Giovannini, A. (1991). Currency substitution and the fluctuations of foreign-exchange reserves with credibly fixed exchange rates. NBER Working Paper Series, 3636. Retrieved from http://www.nber.org/papers/w3636.pdf\#search='Currency+substitution+and+the+fluctuations + of + foreignexchan ge+reserves + with + credibly+fixed+exchange + rates'

Giovannini, A., \& Turtelboom, B. (1994). Currency substitution. In F. van der Ploeg (Ed.), The handbook of international macroeconomics (pp. 390-436). Oxford, UK: Blackwell.

Girton, L., \& Roper, D. (1981). Theory and implications of currency substitution. Journal of Money, Credit, and Banking, 13(1), 12-30. http://dx.doi.org/10.2307/1991805

Guidotti, P. E., \& Rodriguez, C. A. (1992). Dollarization in Latin America: Gresham's law in reverse? IMF Staff Papers, 39(3), 518-544. http://dx.doi.org/10.2307/3867472

International Monetary Fund. (2014). International Financial Statistics, CD- ROM.

Ize, A., \& Levy-Yeyati, E. (2003). Financial dollarization. Journal of International Economics, 59(2), 323-347. http://dx.doi.org/10.1016/S0022-1996(02)00017-X

Kareken, J., \& Wallace, N. (1981). On the indeterminacy of equilibrium exchange rates. Quarterly Journal of Economics, 96(2), 207-222. http://dx.doi.org/10.2307/1882388

Kumamoto, H., \& Kumamoto, M. (2003a). GMM estimation of currency substitution in Latin America. Ajia Keizai, 
44(4), 50-59 (in Japanese).

Kumamoto, H., \& Kumamoto, M. (2003b). The empirical analysis of currency substitution in Latin American countries based on ARDL approach. Journal of International Development Studies, 12(2), 81-96 (in Japanese).

Kumamoto, H., \& Kumamoto, M. (2004). Currency substitution and exchange rate volatility: The case of Mexico. Latin America Ronshu, 38, 1-18 (in Japanese).

Kumamoto, H., \& Kumamoto, M. (2008). Currency substitution, network externalities and hysteresis effects. Journal of Commerce, Economics and Economic History, 77(1), 1-13. Retrieved from http://hdl.handle.net/10270/726

Mizen, P., \& Pentecost, E. J. (1994). Evaluating the empirical evidence for currency substitution: A case study of the demand for sterling in Europe. Economic Journal, 104(426), 1057-1069. http://dx.doi.org/10.2307/2235064

Mongardini, J., \& Mueller, J. (2000). Ratchet effects in currency substitution: An application to the Kyrgyz Republic. IMF Staff Papers, 47(2), 218-237. $\quad$ Retrieved from http://www.imf.org/external/Pubs/FT/staffp/2000/00-02/pdf/mongardi.pdf

National Bank of Tajikistan. Retrieved from http://www.nbt.tj/en/

Neanidis, K. C., \& Savva, C. S. (2009). Financial dollarization: Short-run determinants in transition economies. Journal of Banking \& Finance, 33(10), 1860-1873. http://dx.doi.org/10.1016/j.jbankfin.2009.04.017

Peiers, B., \& Wrase, J. (1997). Dollarization hysteresis and network externalities: Theory and evidence from an informal credit market. Federal Reserve Bank of Philadelphia Working Paper, 97-21. Retrieved from http://www.philadelphiafed.org/research-and-data/publications/working-papers/1997/wp97-21.pdf

Pesaran, M. H., \& Pesaran, B. (1997). Microfit 4.0 (Windows Version). Oxford, Oxford University Press.

Pesaran, M. H., \& Shin, Y. (1999). An autoregressive distributed lag modeling approach to cointegration analysis. In S. Strøm (Ed.), Econometrics and economic theory in the 20th century: The Ragnar Frisch Centennial Symposium (pp.371-413). Cambridge, Cambridge University Press. http://dx.doi.org/10.1017/CCOL521633230.011

Polski Portal Finansowy. Retrieved from http://www.nbp.pl/Homen.aspx?f=/srodeken.htm

Ramirez-Rojas, C. L. (1985). Currency substitution in Argentina, Mexico, and Uruguay. IMF Staff Papers, 32(4), 629-667. http://dx.doi.org/10.2307/3866742

Rodríguez, M. C. \& Turner, P. (2003). Currency substitution and the demand for money in Mexico. Applied Economics Letters, 10(1), 59-62. http://dx.doi.org/10.1080/1350485022000035868

Rogers, J. H. (1990). Foreign inflation transmission under flexible exchange rates and currency substitution. Journal of Money, Credit, and Banking, 22(2), 195-208. http://dx.doi.org/10.2307/1992307

Sarno, L. (2005). Viewpoint: Towards a solution to the puzzles in exchange rate economics: Where do we stand? Canadian Journal of Economics, 38(3), 673-708. http://dx.doi.org/10.1111/j.0008-4085.2005.00298.x

Sawada, Y., \& Yotopoulos, P. A. (2002). Currency substitution, speculation and crises: Theory and empirical analysis. Stanford University Working Paper, 01-23. Retrieved from http://www.stanford.edu/ yotopoul/currency/currency.pdf\#search='Currency+substitution $\% 2 \mathrm{C}+$ speculation + an $\mathrm{d}+$ crises\%3A+Theory+and+empirical+analysis'

Sharma, S. C., Kandil, M., \& Chaisrisawatsuk, S. (2005). Currency substitution in Asian countries. Journal of Asian Economics, 16(3), 489-532. http://dx.doi.org/10.1016/j.asieco.2005.04.013

Stix, H. (2011). Euroization: What factors drive its persistence? Household data evidence for Croatia, Slovenia and Slovakia. Applied Economics, 43(21), 2689-2704. http://dx.doi.org/10.1080/00036840903357413

The Central Bank of Hungary. Retrieved from http://english.mnb.hu/

Uribe, M. (1997). Hysteresis in a simple model of currency substitution. Journal of Monetary Economics, 40(1), 1299-1303. http://dx.doi.org/10.1016/S0304-3932(97)00038-X

Us, V. (2003). Analyzing the persistence of currency substitution using a ratchet variable: The Turkish case. Emerging Markets Finance and Trade, 39(4), 58-81. Retrieved from http://www.jstor.org/stable/27750351

Végh, C. A. (2013). Open economy macroeconomics in developing countries (1st ed.). Cambridge, Mass.: MIT Press. 


\section{Notes}

Note 1. See Giovannini and Turtelboom (1994) and Végh (2013) for surveys on currency substitution.

Note 2. Two other factors explain the ratchet effects of currency substitution. One is based on the fixed costs of switching the currency denomination of transactions. Once the economy has reached an equilibrium in which foreign currency is used for many transactions, it would be costly to switch back to an equilibrium in which only the domestic currency is used. In other words, there is an inaction band within which the currency substitution ratio will not change even if domestic inflation falls (Guidotti \& Rodriguez, 1992). The other is based on the volatility of real exchange depreciation and inflation. Ize and Levy-Yeyati (2003) use a portfolio model in which the equilibrium level of currency substitution depends on the relative price and real exchange rate volatility, and show that if real exchange depreciation is less volatile than inflation, then residents would prefer to hold foreign currency as it is less risky.

Note 3. Examples of previous studies for Latin America countries: Rodríguez and Turner (2003) study on Mexico; Ramirez-Rojas (1985) on Argentina, Mexico, and Uruguay; Clements and Schwartz (1993) on Bolivia; and Kumamoto and Kumamoto (2003a) on Argentina, Bolivia, Chile, Paraguay, Peru, and Uruguay. For Asian countries: Adam, Goujon, and Guillaumont (2004) on Vietnam; Sharma, Kandil, and Chaisrisawatsuk (2005) on Indonesia, Japan, Korea, Malaysia, Singapore, and Thailand; and Kumamoto and Kumamoto (2008) on Indonesia. For Central and Eastern European countries: Neanidis and Savva (2009) on Armenia, Bulgaria, the Czech Republic, Estonia, Georgia, the Kyrgyz Republic, Latvia, Poland, Romania, Russia, and Ukraine; and Stix (2011) on Croatia, Slovenia, and Slovakia.

Note 4. For a discussion on the puzzle and a review of the related literature, see Sarno (2005), Chakraborty, and Evans (2008).

Note 5. The derivation of uncovered interest parity is as follows. Domestic and foreign real interest rates can be defined via Fisher's consumption-based equation as $\left.1+r_{t}=\left\{P_{t}\left(1+i_{t}\right)\right\} E_{t}\left[u_{C}(t+1) / P_{t+1}\right]\right\} / E_{t}\left[u_{C}(t+1)\right]=P_{t}\left(1+i_{t}\right) / E_{t}\left[P_{t+1}\right]$ and $\left.1+r_{t}{ }^{*}=\left\{P_{t}^{*}\left(1+i_{t}{ }^{*}\right)\right\} E_{t}\left[u_{C}(t+1) / P_{t+1}{ }^{*}\right]\right\} / E_{t}\left[u_{C}(t+1)\right]=P_{t}{ }^{*}\left(1+i_{t}{ }^{*}\right) / E_{t}\left[P_{t+1}{ }^{*}\right]$, where $P_{t}$ and $P_{t}{ }^{*}$ denote the currency prices of the consumption good at period $t$. Taking the natural logarithms of the two above equations and using the relationship $r_{t}=r_{t}^{*}$ (note that real interest rates are determined by world investment-saving balances; therefore, real interest rates must equalize across countries) and the purchasing power parity, we obtain a desirable result.

Note 6. The ratchet effects in currency substitution are investigated by Mongardini and Mueller (2000) for the Kyrgyz Republic; Kumamoto and Kumamoto (2003b) for Argentina, Bolivia, Mexico, Paraguay, Peru, and Uruguay; and Us (2003) for Turkey with an ARDL approach. Although Mongardini and Mueller (2000) and Us (2003) introduce the expected change in the nominal exchange rate as one of the determinants of currency substitution, they do not consider the forward premium puzzle.

Note 7. The simple $\operatorname{GARCH}(1,1)$ model has been found to provide a good representation of a wide variety of volatility processes (Bolleslev, 1986).

Note 8. Pesaran and Shin (1999) show that the OLS estimators of the short-run parameters are $\sqrt{T}$-consistent with the asymptotically singular covariance matrix and the long-run parameters are $T$-consistent (super consistent), and that valid inferences on the long-run parameters can be made according to the standard normal asymptotic theory.

Note 9. Residents include non-financial incorporated enterprises and households, excluding private banks, the central bank, and the government.

Note 10. With the available data, we cannot determine whether residents hold deposits denominated in foreign currency as a medium of exchange for domestic or foreign transactions. Therefore, we might overestimate the degree of currency substitution.

Note 11. Data are not available for the treasury bill rate in Indonesia, Tajikistan, Argentina, and Peru; the interbank offered rate in Tajikistan; and the deposit rate on foreign currency deposits in the Czech Republic.

Note 12. All econometric results were computed with the Microfit 4.1 software package for Windows, designed by Pesaran and Pesaran (1997).

Note 13. We confirm the robustness of the empirical result for Eastern European countries using IBOR, defined as the average monthly yield difference between the three-month interbank offered rate of the respective countries and the three-month Euro Interbank Offered Rate (EURIBOR). 